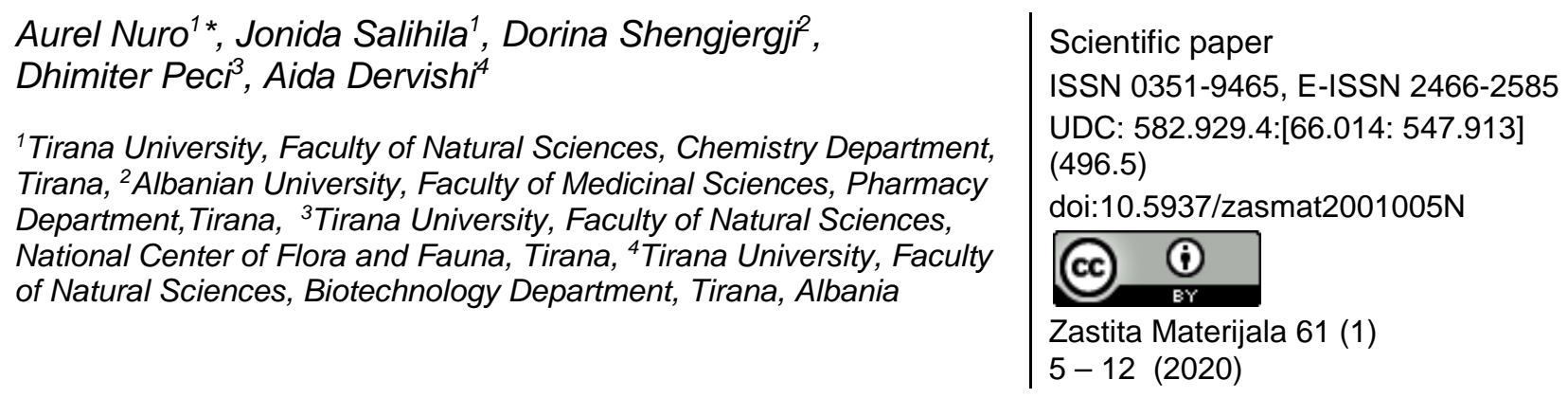

\title{
Chemical composition of essential oil for Thymus population from Albania
}

\begin{abstract}
This study presents data about chemical composition of essential oils for Thymus populations from the Albania. The genus Thymus contains about 350 species of aromatic plants in the family Lamiaceae. It is in the form of a beautiful shrub with numerous branches used often as decorative plant besides it uses for culinary and medical purposes. Thymus plants are part of spontaneous flora in Albania and almost throughout the Mediterranean areas.

Thymus vulgaris, Thymus capitatus and Thymus serpyllum samples from different areas of Albania were taken in July 2017. The air dried plant samples were cut in small pieces $(1-2 \mathrm{~cm})$ and after that were subjected to European Pharmacopoeia apparatus (Clevenger type) for 4 hours to obtain Thymus essential oil. The chemical composition of essential oils was analyzed using GC/FID technique. The oil of each Thymus samples was injected in a Varian $450 \mathrm{GC}$. VF-1ms capillary column (30 $\mathrm{m} \times 0.33 \mathrm{~mm} \times$ $0.25 \mathrm{um}$ ) were used for separation of compounds. 40-65 compounds were found in analyzed samples. Para-Cymene, gama-Terpinen, Thymol and Carvacrol were identified as main constituents and all analyzed essential oils of Thymus samples from Albania. Para-Cymene was the main constituent for Thymus vulgaris samples. Carvacrol was found in higher percentage for Thymus capitatus and Thymus serpyllum. Thymol was in higher percentage for Thymus vulgaris and Thymus serpyllum. Total of Thymol and Carvacrol were higher for Thymus serpyllum samples. The same compounds were found for all Thymus samples but were noted differences in percentage between them. This is related with differences between species obtained for analysis but is not excluded the impact of geographic and geological factors. Data reported in this paper were similar to those published in previous works in Balkan and Mediterranean area.
\end{abstract}

Keywords: Thymus; Esencial oil; p-Cymene; gama-Terpinen; Thymol; Carvacrol; GC/FID.

\section{INTRODUCTION}

The genus Thymus contains about 350 species of aromatic plants in the family Lamiaceae, native to temperate regions in Europe, North Africa and Asia. Stems tend to be narrow or even wiry; leaves are evergreen in most species, arranged in opposite pairs, oval, entire, and small, 4-20 mm long, and usually aromatic. Flowers of Thyme are in dense terminal heads, with an uneven calyx, with the upper lip three-lobed, yellow, white or purple. Several members of the genus are cultivated as culinary herbs or ornamentals, when they are also called thyme after its best-known species, Thymus vulgaris or common thyme $[1,2]$.

*Corresponding author: Aurel Nuro

E-mail: aurel.nuro@fshn.edu.al

Paper received: 6.10.2019.

Paper accepted: 2.11.2019.

Paper is available on the website: www.idk.org.rs/journal
Thymus vulgaris is a species of flowering plant in the mint family Lamiaceae, native to southern Europe from the western Mediterranean to southern Italy. Growing to $15-30 \mathrm{~cm}$ tall by 40 $\mathrm{cm}$ wide, it is a bushy, woody-based evergreen subshrub with small, highly aromatic, grey-green leaves and clusters of purple or pink flowers in early summer. It is useful in the garden as groundcover, where it can be short-lived, but is easily propagated from cuttings. It is also the main source of thyme as an ingredient in cooking and as an herbal medicine. It is slightly spicier than oregano and sweeter than sage.

Thymus capitatus is a compact, woody perennial native to Mediterranean Europe and Turkey. It is also known under the name Thymbra capitata. The plant has rising stems and narrow green leaves to $12 \mathrm{~mm}$ long. The pink flowers, 10 $\mathrm{mm}$ long, are held in cone-shaped clusters at the ends of their stems in mid to late summer; they are protected by overlapping, $6 \mathrm{~mm}$-long, red-tinged bracts, edged in tiny hairs. 
Thymus serpyllum, is a species of flowering plant in the mint family Lamiaceae, native to most of Europe and North Africa. It is a low, usually prostrate subshrub growing to $2 \mathrm{~cm}$ tall with creeping stems up to $10 \mathrm{~cm}$ long. The oval evergreen leaves are 3-8 $\mathrm{mm}$ long. The strongly scented flowers are either lilac, pink-purple, magenta, or a rare white, all 4-6 mm long and produced in clusters. The hardy plant tolerates some pedestrian traffic and produces odors ranging from heavily herbal to lightly lemon, depending on the variety.

Thyme population is a popular traditional medicine and culinary [3]. They are found in most parts of Albania and easy to harvest. They are mainly used for respiratory ailments but many other uses have also been recorded. Thymus species are herb with a wide range of pharmacological properties such as antimicrobial, gastrointestinal, and nervous system effects. Studies carried out on the chemical composition of the plant have shown that the main chemical compounds present in Thymus essential oil are monoterpenes, particularly aromatic and oxygenated ones. Essential oils derived from Thymus have valuable pharmacological properties that have been investigated by many scientists around the world.
Due to their antimicrobial, insecticidal, antifungal, and antibacterial activities, essential oils have been intensely screened and applied in the fields of pharmacology, medical and clinical micro-biology, phytopathology and food preservation $[4,5]$.

\section{MATERIALS AND METHODS}

\subsection{Reactive and standards}

Toluene (chromatographic grade) was purchased from Merck (Darmstadt, Germany). A mixture of n-alkanes (Sigma Aldrich) from n-octane (C8) to eicosanes (C20) was used for calculation of Kovats indices $(\mathrm{KI})$.

\subsection{Sampling of Thymus population from Albania}

Thymus vulgaris (TV), Thymus capitate (TC) and Thymus serpillium (TS) samples were taken from population of South-East Albania: Pogradeci (2TV, 1TC and 1TS samples); Korca (2TV and 1TC samples); Librazhdi (2TV and 1TS samples) and Kolonja (2TV samples). Thymus herbs were sampled in July 2017. The sampling site of Thymus plants was shown in Figure 1. Areal parts (branches, leaves and flowers) of Thymus populations were consider in this study. Plants were air dried in shadow for saving their morphological characteristics.

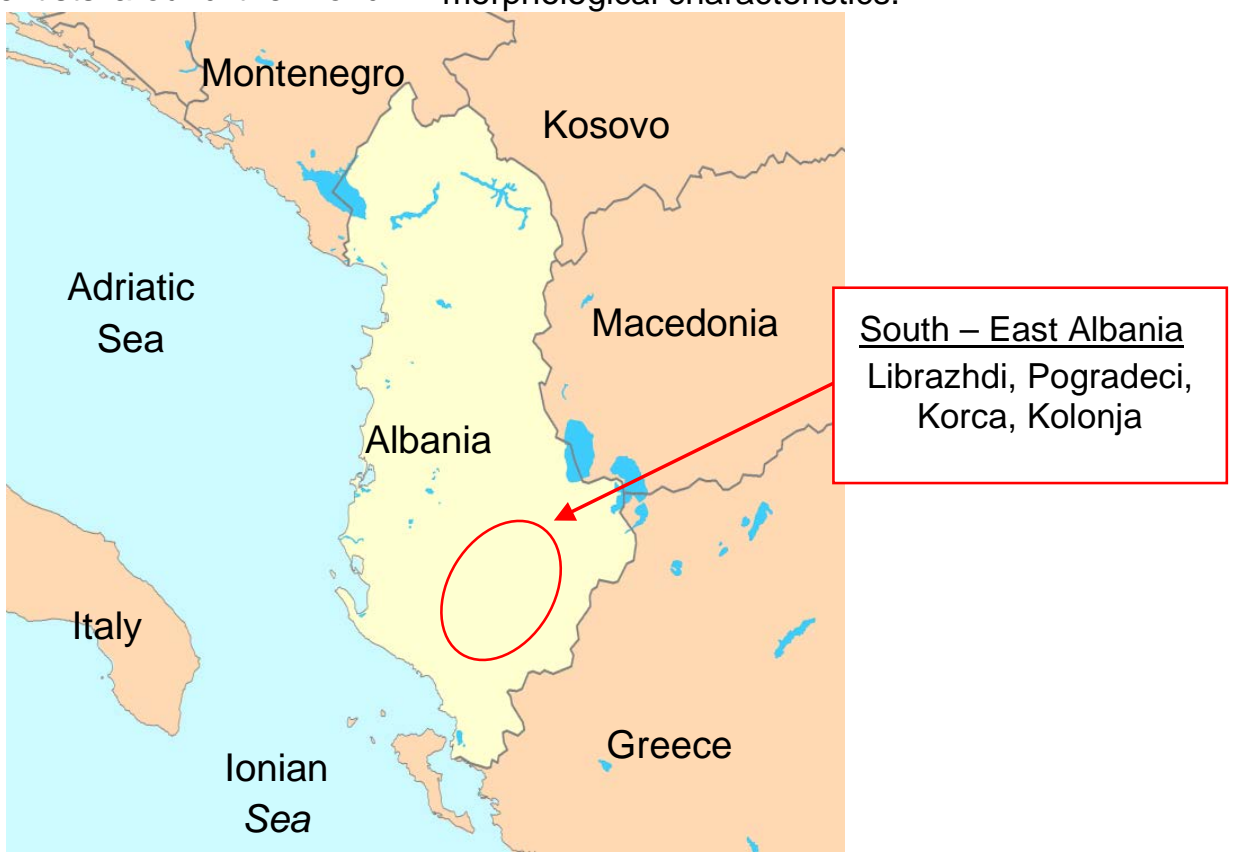

Figure 1. The map of sampling site for Thymus populations, July 2017

Slika 1. Mapa mesta za uzorkovanje Thymus populations, juli 2017

\subsection{Isolation of Thymus essential oil}

Air dried plant material of Thymus vulgaris, Thymus capitate and Thymus serpillium were cut in small pieces $(0.5$ to $2 \mathrm{~cm})$ before analyze. $50 \mathrm{~g}$ of plant material was subjected to hydrodistillation for $4 \mathrm{~h}$, using a modified Clevenger-type apparatus to produce essential oil. $1 \mathrm{ml}$ Toluene was added to the balloon for isolation of Mentha essential oils. The oil was dried by anhydrous sodium sulfate $\left(\mathrm{Na}_{2} \mathrm{SO}_{4}\right)$ and kept sealed in dark glass vial at +4 ${ }^{\circ} \mathrm{C}$ until use. Diluted essential oil in Toluene was used for GC/FID analyses. 


\subsection{Apparatus and chromatography}

Gas chromatographic analyses of Thyme essential oil were realized with a Varian $450 \mathrm{GC}$ instrument equipped with a flame ionization detector and PTV detector. The temperature of PTV injector was $280^{\circ} \mathrm{C}$. $1 \mathrm{ul}$ of each Thymus essential oil diluted in Toluene was injected in splitless mode. A temperature for FID was held at $280^{\circ} \mathrm{C}$. Nitrogen was used as carrier $(1 \mathrm{ml} / \mathrm{min})$ and make-up gas $(25 \mathrm{ml} / \mathrm{min})$. Hydrogen and air were flame detector gases with $30 \mathrm{ml} / \mathrm{min}$ and 300 $\mathrm{ml} / \mathrm{min}$, respectively. VF-1ms capillary column (30 $\mathrm{m} \times 0.33 \mathrm{~mm} \times 0.25 \mu \mathrm{m}$ ) was used to isolate compounds of Thymus essential oil. The oven temperature was programmed as follows: $40^{\circ} \mathrm{C}$ (held for 2 minutes) to $150^{\circ} \mathrm{C}$ (with $4^{\circ} \mathrm{C} / \mathrm{min}$ ), after that to $280{ }^{\circ} \mathrm{C}$ with $10^{\circ} \mathrm{C} / \mathrm{min}$ and held for 2 minutes. The identification of the compounds was based on comparison of their Kovats indices $(\mathrm{KI})$, their retention times (RT) and literature[6-9]. Chromatogram of the Thymus essential oil for sample site Pogradeci, South-East Albania sample was shown in Figure 2.

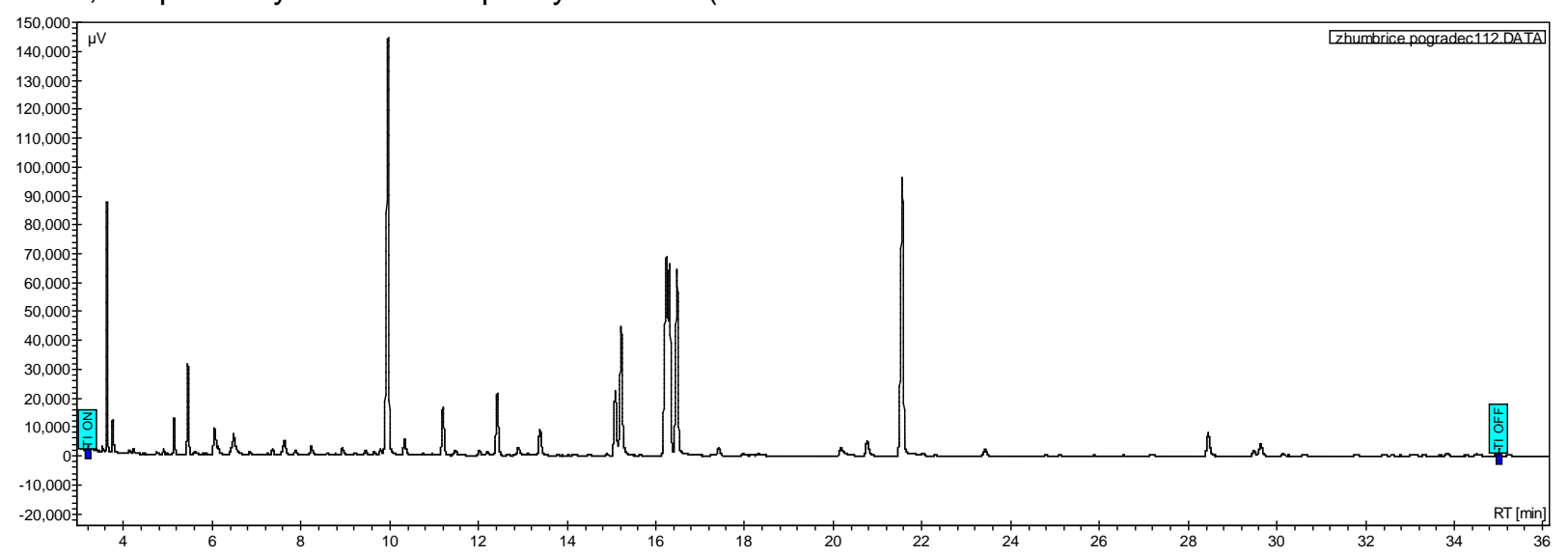

Figure 2. Chromatogram of Thymus vulgaris essential oil for Pogradeci sample 1, July 2017

Slika 2. Hromatogram eteričnog ulja Thymus vulgaris za uzorke Pogradeci 1, juli 2017

\section{RESULTS AND DISCUSSION}

Essential oil of Thymus vulgaris, Thymus capitate and Thymus serpillium samples from Librazhdi, Pogradeci, Korca and Kolonja were analyzed using GC/FID technique. Averages of results were presented in this study. The data were present as percent for the total of peaks except for the peak of Toluene that was solvent used for dilution. For individual Thymus essential oil were found from 60 to 80 compounds. The peaks lower than $0.1 \%$ was not present in this study. The data present a total of 25 the main compounds that were found for all Thymus essential oil by the chromatographic method used. Their averages for the total were: $91.2 \%$ for Thymus vulgaris, $96.8 \%$ for Thymus capitate and $93.1 \%$ for Thymus serpillium for all studied samples. Figure 3 shows the main compounds for Thymus population. ParaCymene, gama-Terpinen, Thymol and Carvacrol were identified as main constituents in all analyzed essential oils of Thymus samples from Albania. Para-Cymene (40.1\%) was the main constituent for Thymus vulgaris samples. Carvacrol $(29.2 \%$ and $18.4 \%$ ) was found in higher percentage for Thymus capitatus and Thymus serpyllum. Thymol (28.2\% and $17.1 \%)$ was in higher percentage for Thymus vulgaris and Thymus serpyllum. Total of Thymol and Carvacrol (45.3\%) were higher for Thymus serpyllum samples. The same compounds were found for all Thymus samples but were noted differences in percentage between them. This is related with differences between species obtained for analysis but is not excluded the impact of geographic and geological factors. Figure 4 shown profile for terpene classes in esential oil of Thymus samples. Monoterpenes were in higher percentage in all analyzed samples from $87.1 \%$ (TC) to $93.2 \%$ (TV). The profile of main monoterpene classes were: aromatic monoterpene $>$ oxygenated monoterpenes $>$ monocyclic monoterpene $>$ bicyclic monoterpene $>$ aliphatic monoterpene $>$ tricyclic monoterpene. Figure 5 shown the largest group of monoterpene were aromatic monoterpenes (para-Cymene, Thymol and Carvacrol) ranging from $50.8 \%$ (TS) to $76.4 \%$ (TV). Para-Cymene and Thymol were found in higher percentage in Thymus vulgaris samples while Carvacrol was found in higher percentage for Thymus capitatea samples. Figure 6 present percentages of oxygenated terpenoids: Cineole, Terpinolene, Linalool, Camphour, Borneol, Terpinen-4-ol, Cimenol-8, gama-Terpineol, Nerol, Pulegon/Citroneol. They were found from $10.1 \%$ (TV) to $26.7 .1 \%$ (TS). They were the second group of terpenoic groups. Linalool was the main compound for Thymus capitate and Thymus serpyllium. 
Table 1. Percentages of main compounds in analyzed Thymus essential oil samples, 2017

Tabela 1. Procenti glavnih jedinjenja $u$ analiziranim uzorcima esencijalnog ulja Thymusa, 2017

\begin{tabular}{|l|c|c|c|}
\hline & $\begin{array}{c}\text { Thymus } \\
\text { capitata }\end{array}$ & $\begin{array}{c}\text { Thymus } \\
\text { vulgaris }\end{array}$ & $\begin{array}{c}\text { Thymus } \\
\text { serpyllium }\end{array}$ \\
\hline Triciklen & 0.825 & 0.81 & 0.61 \\
\hline alfa-Pinene & 1.215 & 1.825 & 1.68 \\
\hline Kamfen & 1.13 & 1.05 & 1.32 \\
\hline beta-Pinene & 1.83 & 1.18 & 1.56 \\
\hline Miricen & 0.79 & 0.735 & 1.1 \\
\hline alfa-Terpinen & 1.385 & 0.755 & 1.09 \\
\hline para-Cimen & 13.305 & 40.095 & 20.53 \\
\hline Limonen & 0.925 & 0.665 & 1.73 \\
\hline Cineole & 1.485 & 0.915 & 2.59 \\
\hline gama-Terpinen & 0.785 & 5.595 & 1.18 \\
\hline Cis-Sabinenhidrat & 0.325 & 0.255 & 0.53 \\
\hline Terpinolen & 0.255 & 0.235 & 0.25 \\
\hline Linaleol & 10.115 & 1.105 & 10.59 \\
\hline Kamfur & 0.855 & 0.52 & 1.51 \\
\hline Borneol & 1.595 & 2.345 & 3.05 \\
\hline Terpinen-4-ol & 0.75 & 1.095 & 1.53 \\
\hline
\end{tabular}

\begin{tabular}{|l|c|c|c|}
\hline Cimenol-8 & 0.46 & 1.18 & 0.53 \\
\hline g-Terpineol & 0.47 & 0.825 & 0.12 \\
\hline Nerol & 2.565 & 1.52 & 4.28 \\
\hline Pulegon/Citroneol & 0.485 & 0.59 & 2.24 \\
\hline Timol & 16.4 & 27.405 & 11.51 \\
\hline Karvakrol & 29.09 & 2.495 & 17.8 \\
\hline beta-Karafilen & 2.845 & 2.07 & 4.74 \\
\hline Humulen & 0.855 & 1.28 & 0.62 \\
\hline Germacen & 0.495 & 0.295 & 0.42 \\
\hline Total & 91.235 & 96.84 & 93.11 \\
\hline $\begin{array}{l}\text { Total } \\
\text { Monoterpene }\end{array}$ & 87.04 & 93.195 & 87.33 \\
\hline $\begin{array}{l}\text { Aliphatic } \\
\text { Monoterpene }\end{array}$ & 0.79 & 0.735 & 1.1 \\
\hline $\begin{array}{l}\text { Monocyclic } \\
\text { Monoterpene }\end{array}$ & 3.35 & 7.25 & 4.25 \\
\hline $\begin{array}{l}\text { Bicyclic } \\
\text { Monoterpene }\end{array}$ & 4.5 & 4.31 & 5.09 \\
\hline $\begin{array}{l}\text { Tricyclic } \\
\text { monoterpene }\end{array}$ & 0.825 & 0.81 & 0.61 \\
\hline $\begin{array}{l}\text { Oxcygenated } \\
\text { monoterpene }\end{array}$ & 18.78 & 10.095 & 26.44 \\
\hline $\begin{array}{l}\text { Aromatic } \\
\text { monoterpene }\end{array}$ & 58.795 & 69.995 & 49.84 \\
\hline Sesquiterpene & 4.195 & 3.645 & 5.78 \\
\hline
\end{tabular}

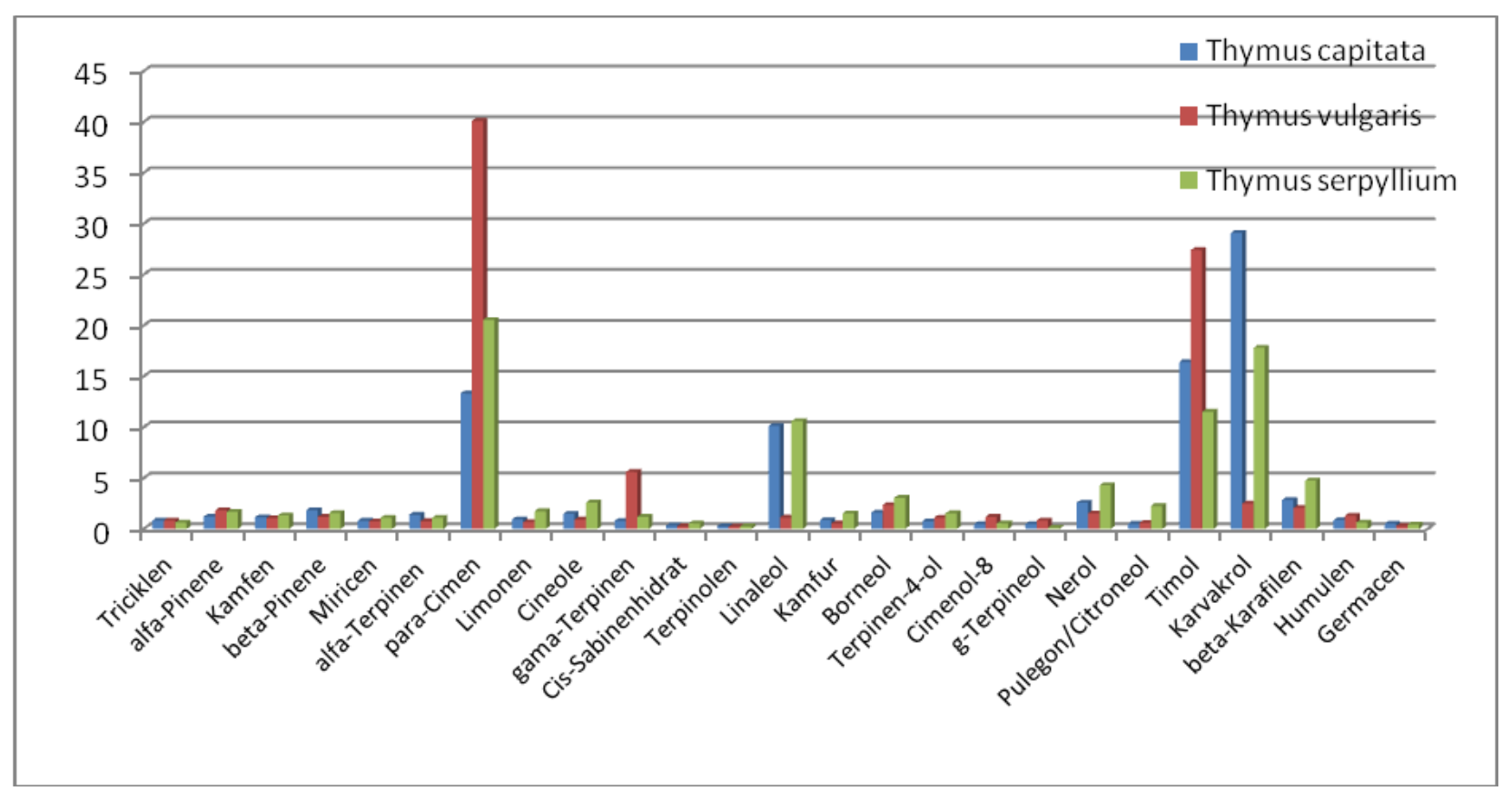

Figure 3. Main compounds in analyzed essential oil of Thymus samples, 2017

Slika 3. Glavna jedinjenja u analiziranim esencijalnim uljima uzoraka Thymusa, 2017 


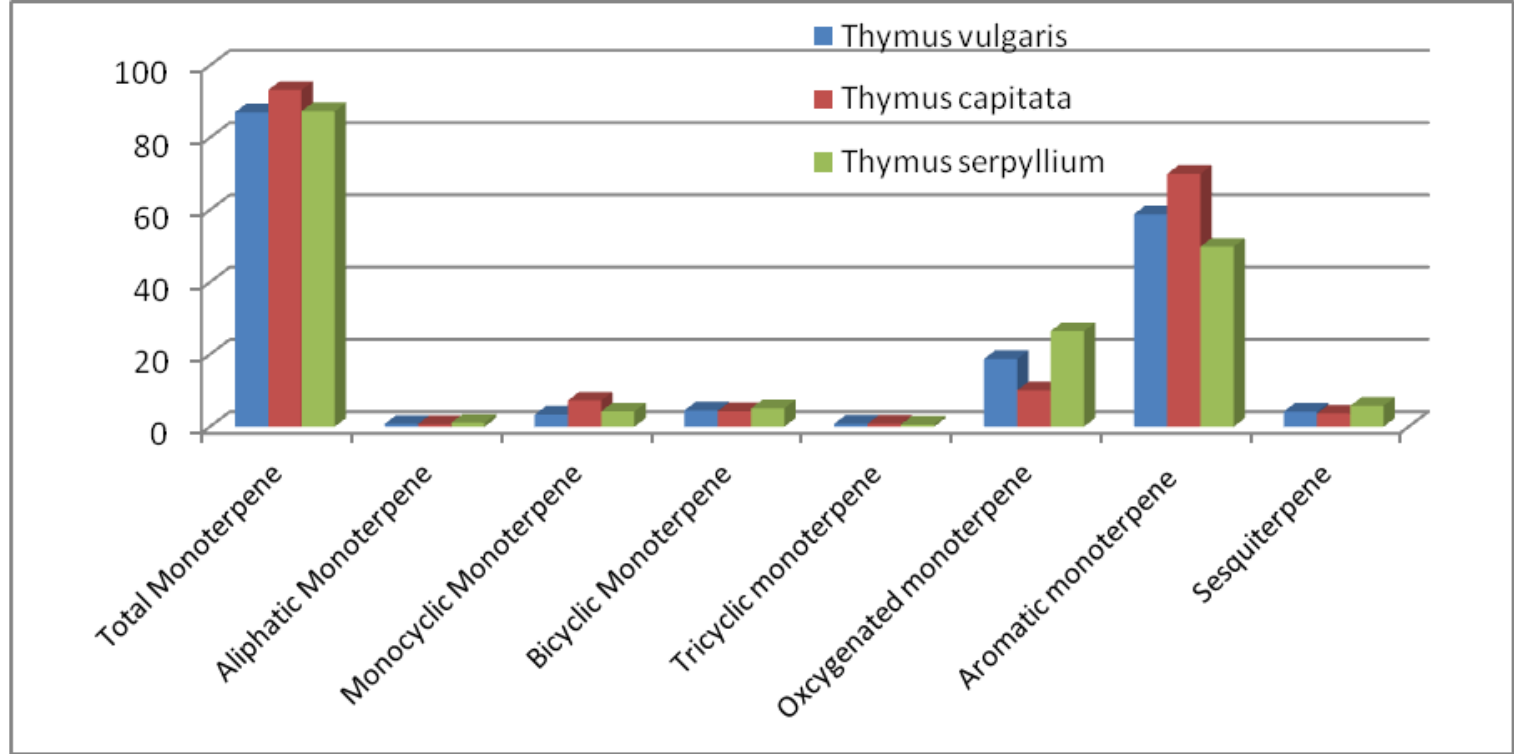

Figure 4. Profile of terpene classes in essential oil of Thymus population samples

Slika 4. Profil klasa terpena u uzorcima esencijalnog ulja thymusa

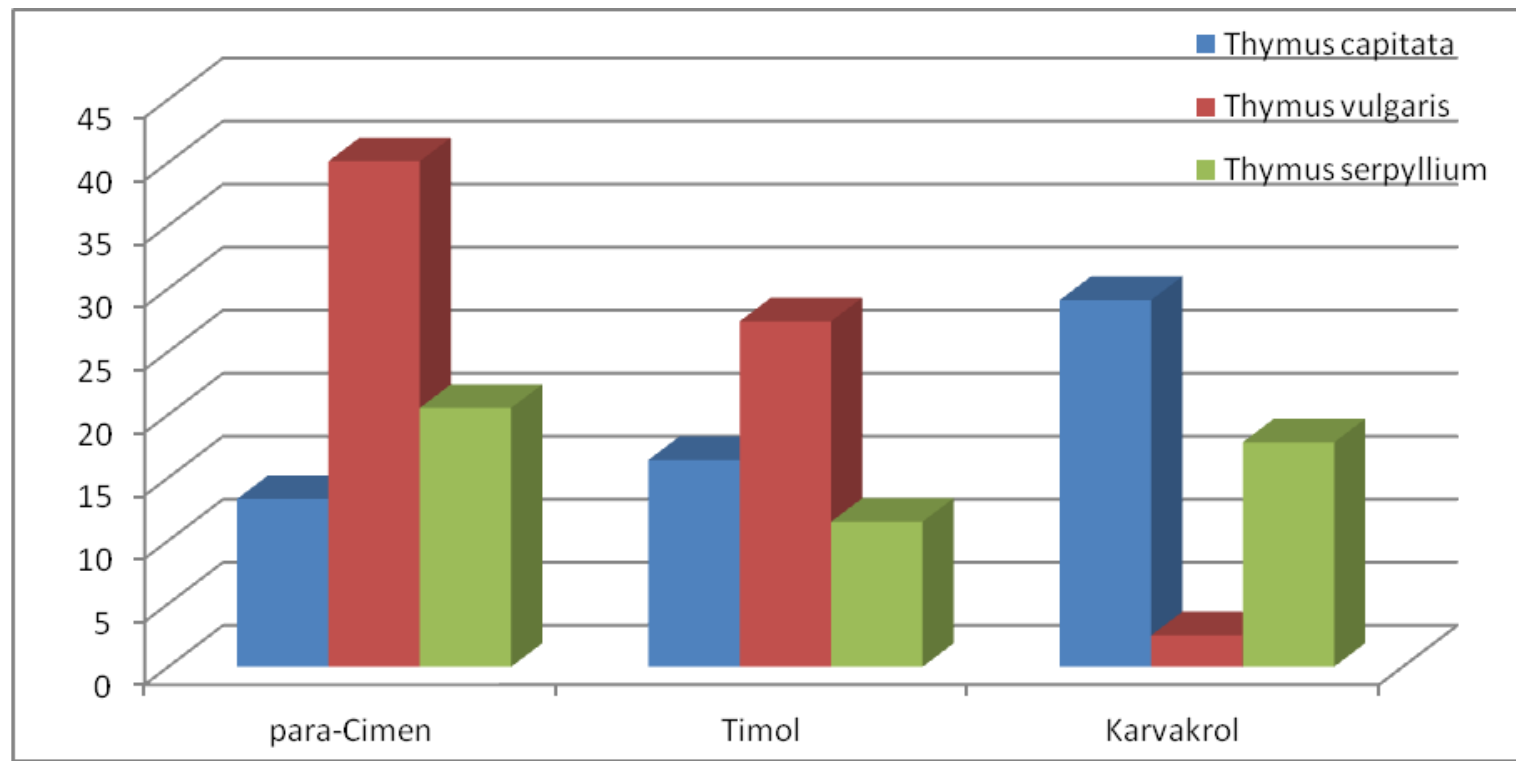

Figure 5. Percentages of aromatic monoterpenes in analyzed Thymus essential oil samples

Slika 5. Procenti aromatičnih monoterpena u analiziranim uzorcima eteričnog ulja Thymusa

Figure 7 shown monocyclic monoterpenes (alpha-Terpinene, Limonene, gamma-Terpinene and Terpinolene) ranged from $2.0 \%$ (TC) to $6.6 \%$ (TV). Gamma-Terpinen was found in higher percentage for Thymus vulgaris samples. Figure 8 shown bicyclic monoterpenes (alfa-Pinene, Camphene, cis-Sabinenhydrat and beta-Pinene) that range from $4.6 \%$ (TS) to $6.4 \%$ (TV). Alicyclic monoterpenes (Miricen) were found in range 0.2 1.4\%. Tricyclic monoterpene (Tricyclene) was found in range $0,6 \%$ (TS) to $0.8 \%$ (TC). Figure 9 shown sesquiterpenes (beta-Caryofyllene, alfaHumulene dhe Germacene). Sesquiterpenes were found from $3.7 \%$ (TV) to $5.8 \%$ (TS). BetaCaryophyllene was the main sesquiterpene for all samples. The composition of essential oil derived from Thymus populations from Albania is related mainly with Thymus type. Other factors that can affect in differences between Thymus populations could be: the maturity time, the sampling time of 
the plants, its dry process, atmospheric condition (especially the sea level, air temperatures, humidity, etc.) and the geological composition. Profile and leveles of Thymus vulgaris, Thymus capitatea and Thymus serpyllium populations from Albania were the same with other reported studies from Balkan and Mediterrean area[4].

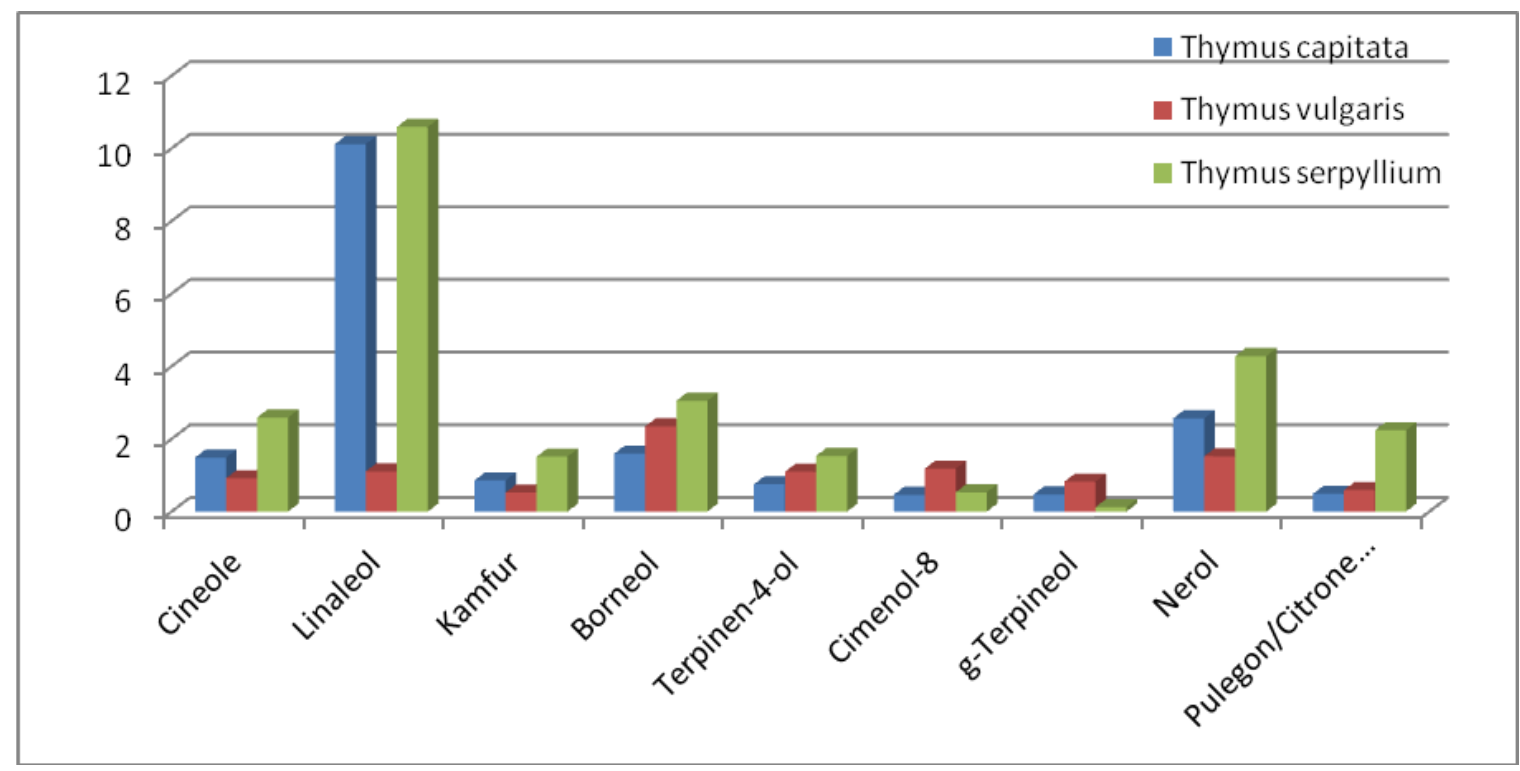

Figure 6. Percentages of oxcygenated monoterpenes in analyzed Thymus essential oil samples Slika 6. Procenti monoterpena sa oksigenizovanim uzorcima u analiziranim uzorcima esencijalnog ulja Thymusa

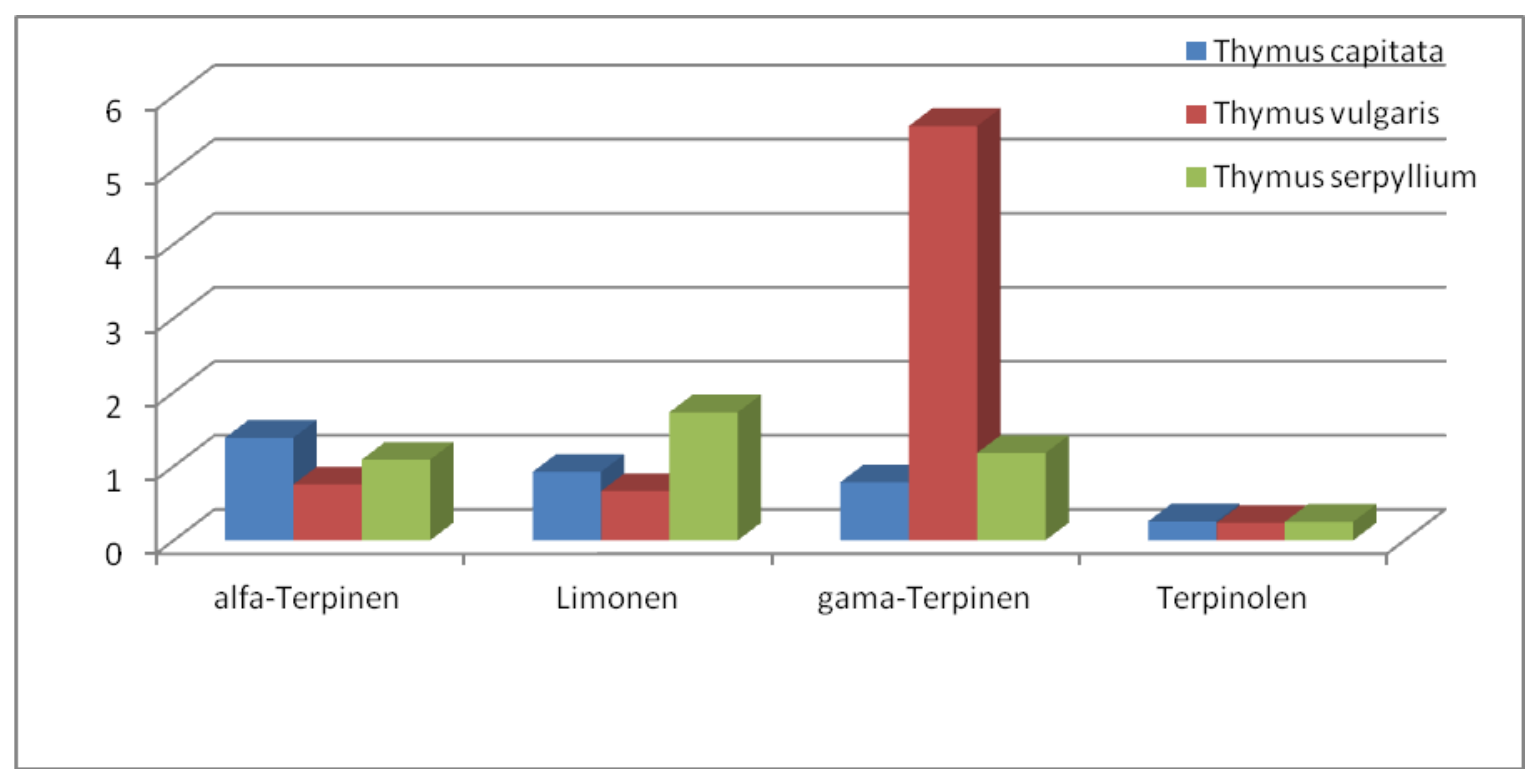

Figure 7. Percentages of monocyclic monoterpenes in analyzed Thymus essential oil samples Slika 7. Procenat monocikličnih monoterpena u analiziranim uzorcima eteričnog ulja Thymusa 


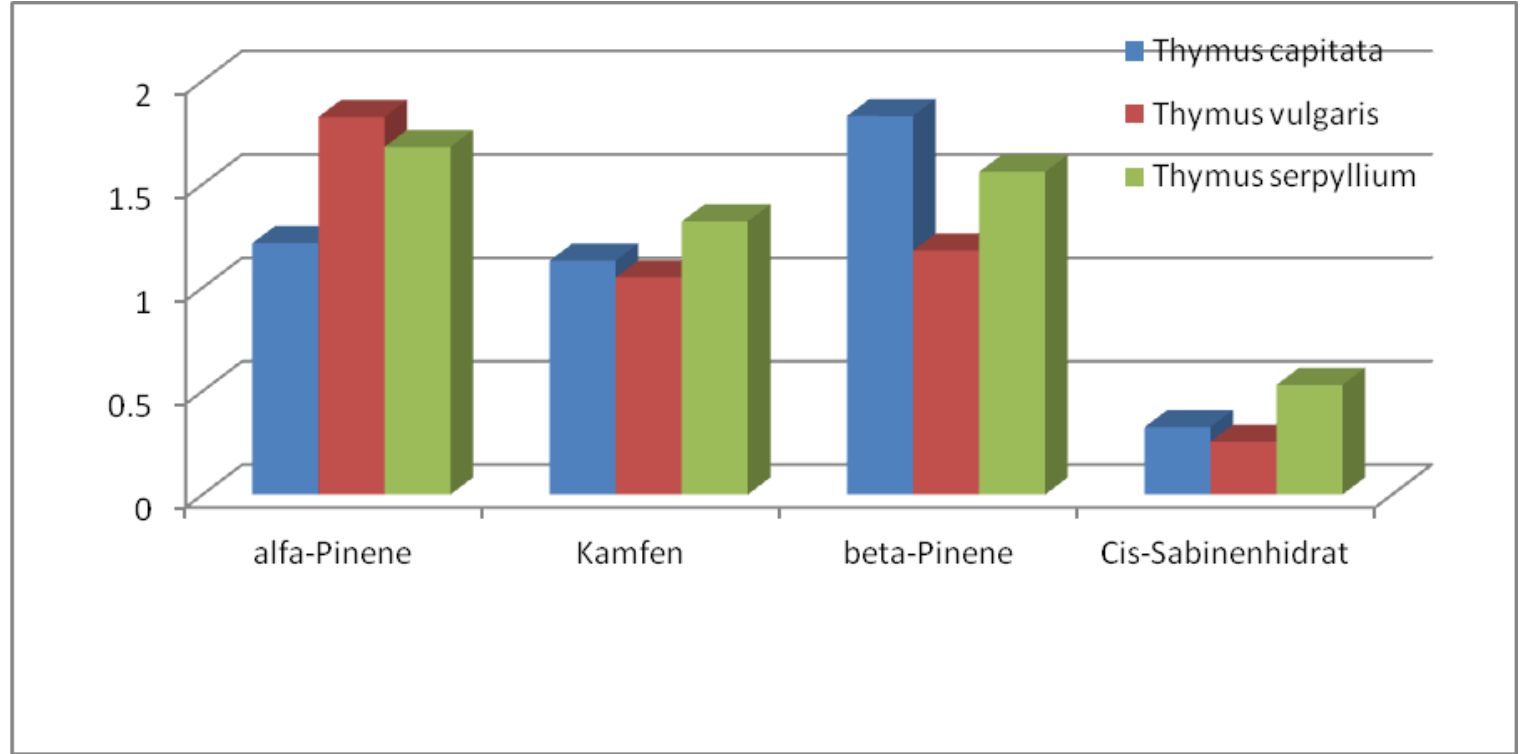

Figure 8. Percentages of bicyclic monoterpenes in analyzed Thymus essential oil samples

Slika 8. Procenti bicikličnih monoterpena u analiziranim uzorcima eteričnog ulja Thymusa

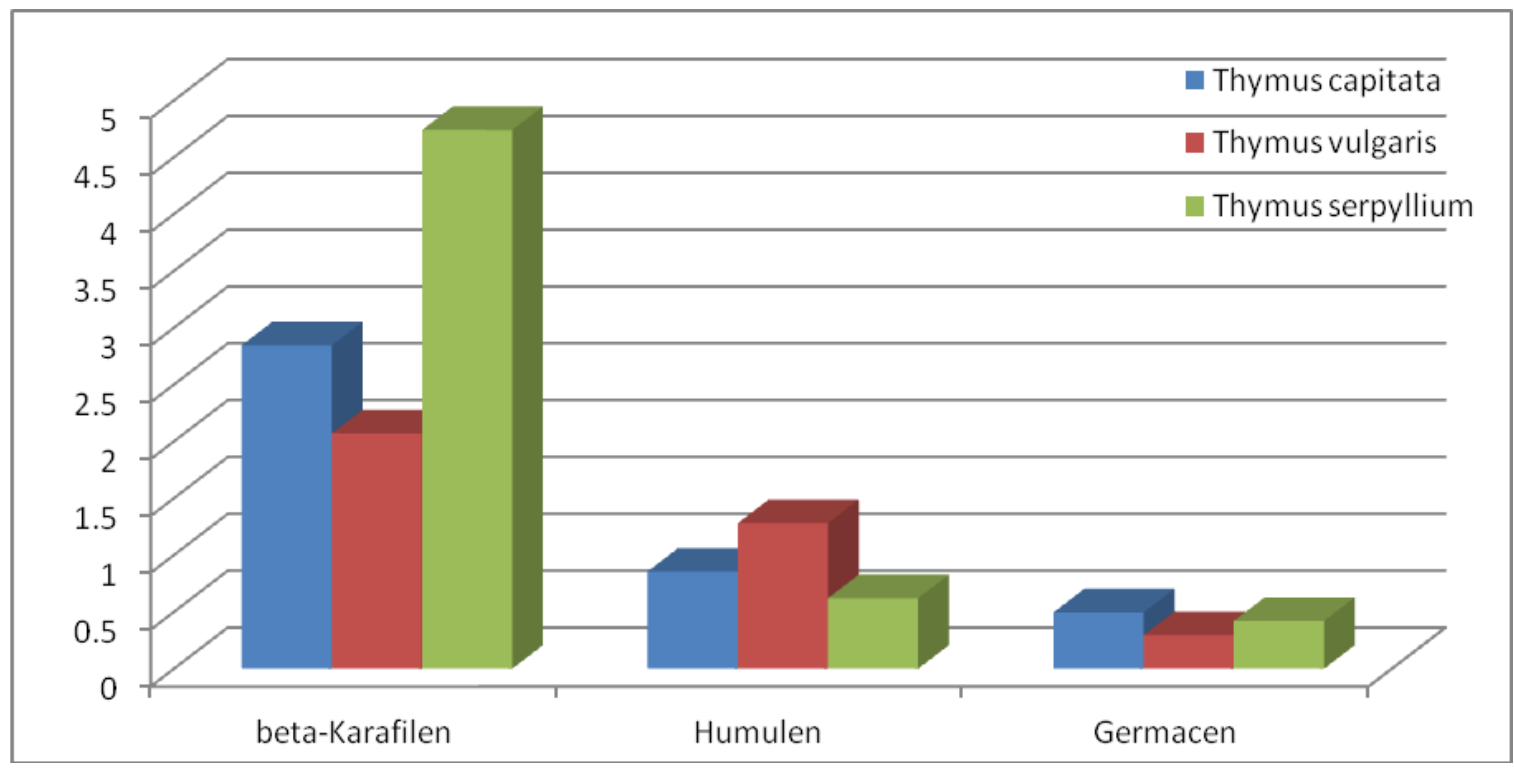

Figure 9. Percentages of sesquiterpenes in analyzed Thymus essential oil samples

Slika 9. Procenti seskviterpena u analiziranim uzorcima esencijalnog ulja Thymusa

\section{CONCLUSIONS}

Thymus vulgaris, Thymus capitate and Thymus serpillium essential oil from different areas of Albania were analyzed using GC/FID technique. For essential oil of Thymus were found from 60 to 80 compounds. The study consider total of 25 the main compounds that were found for all essential oil of analyzed Thyme samples. GC/FID was chromatographic method used for dedection of terpenes in Thyme oil. Para-Cymene, gamaTerpinen, Thymol and Carvacrol were identified as main constituents and all analyzed essential oils of Thymus samples from Albania. Para-Cymene was the main constituent for Thymus vulgaris samples. Carvacrol was found in higher percentage for Thymus capitatus and Thymus serpyllum. Thymol was in higher percentage for Thymus vulgaris and Thymus serpyllum. Total of Thymol and Carvacrol were higher for Thymus serpyllum samples. The same compounds were found for all Thymus samples but were noted differences in percentage between them. This is related with differences between species obtained for analysis but is not excluded the impact of geographic and geological factors. Monoterpenes were in higher percentage in all analyzed samples ranges from $91.2 \%$ (TC) to $96.8 \%$ (TV). Sesquiterpenes were found from 3.7\% 
(TV) to $5.8 \%$ (TS). The profile of main monoterpene classes were: aromatic monoterpene $>$ oxygenated monoterpenes $>$ monocyclic monoterpene $>$ bicyclic monoterpene $>$ aliphatic monoterpene $>$ tricyclic monoterpene. Data reported in this paper were similar to those published in previous works in Balkan and Mediterranean area.

\section{REFERENCES}

[1] B.David (1995) "Wild Flowers of the Mediterranean" ISBN 0-7513-2761-1

[2] T.Tutin (1968) "Flora Europaea", Vol. 2. ISBN 0521-06662-X

[3] K.Wolfgang, H.Susanne, H.Andreas (2003) Medicinal and Aromatic Plants in Albania, BosniaHerzegovina, Bulgaria, Croatia and Romania. A study of the collection of and trade in medicinal and aromatic plants (MAPs), relevant legislation and the potential of MAP use for financing nature conservation and protected areas" WWF Deutschland / TRAFFIC Europe-Germany.
[4] D.J.Daferera, B.N.Ziogas, M.G.Polissiou (2000) GC-MS analysis of essential oils from some Greek aromatic plants and their fungitoxicity on Penicillium digitatum, Jour-nal of Agricultural Food Chemistry, 48, 2576-2581.

[5] N.Sarac, A.Ugur (2007) Antimicrobial activities and usage in folkloric medicine of some Lamiaceae species growing in Mugla, Turkey. Eurasian J Bio Sci., 4, 28-37.

[6] R.P.Adams (1995) Identification of essential oil components by gas chromatography/mass spectroscopy, Allured Publishing Cor-poration, Carol Stream: Illinois, USA.

[7] F.David, F.Scanlan, P.Sandra, M.Szelewski (2010) Analysis of essential oil compounds using retention time locked methods and retention time databases, Application, Agilent Technologies, 5988-6530EN.

[8] W.A.Konig, N.Bulow, Y.Saritas (1999) Identification of sesquiterpene hydrocarbons by gas phase analytical methods, Flavour Fragr. J., 14, 367-378.

[9] B.Bozin, N.Mimica-Dukic, N.Simin, G.Anac-kov (2006) Characterization of the volatile composition of essential oils of some Lamiaceae spices and the antimicrobial and antioxidant activities of the entire oils, J. Agric. Food Chem., 54, 1822-1828.

\section{IZVOD}

\section{HEMIJSKI SASTAV ESENCIJALNOG ULJA ZA POPULACIJU THYMUSA IZ ALBANIJE}

Ova studija prikazuje podatke o hemijskom sastavu esencijalnih ulja za populaciju Thymusa iz Albanije. Rod Thymus sadrži oko 350 vrsta aromatičnih biljaka iz porodice Lamiaceae. U obliku je prekrasnog grmlja s brojnim granama koje se često koriste kao ukrasna biljka, osim što ga koriste u kulinarske $i$ medicinske svrhe. Biljke timijana deo su spontane flore u Albaniji i gotovo u svim mediteranskim oblastima.

Uzorci Thymus vulgaris, Thymus capitatus $i$ Thymus serpyllum iz različitih oblasti Albanije uzeti su u julu 2017. Uzorci biljnih osušenih komada isečeni su u malim komadima $(1-2 \mathrm{~cm})$ i nakon toga podvrgnuti u farmakopejskoj aparaturi (Clevenger tip) u toku 4 sata za dobijanje Thymus esencijalnog ulja. Hemijski sastav esencijalnih ulja je analiziran korišćenjem GC/FID tehnike. Ulje svakog Thymus uzorka ubrizgano je u Varian 450 GC. Za razdvajanje jedinjenja korišćeni su VF-1ms kapilarni stupac (30 mk 0,33 mmk 0,25 um). Nađeno je 40-65 jedinjenja u analiziranim uzorcima.

Para-Cymene, gama-Terpinen, Thymol i Carvacrol identifikovani su kao glavni sastojci i sva analizirana esencijalna ulja uzoraka Thymusa iz Albanije. Para-Cymene je bio glavni sastojak uzoraka Thymus vulgaris. Pronađen je Carvacrol u većem procentu od Thymus capitatus i Thymus serpyllum. Thymol je bio $u$ većem procentu od Thymus vulgaris i Thymus serpyllum. Ukupan broj Thymol-a i Carvacrol bio je veći od uzorka Thymus serpyllum. Pronađena su ista jedinjenja za sve Thymus uzorke, ali su primećene razlike u procentima između njih. Ovo je povezano sa razlikama između vrsta dobijenih tokom analize, ali nije isključen uticaj geografskih i geoloških faktora. Podaci navedeni u ovom radu bili su slični onima objavljenim u prethodnim radovima na području Balkana i Mediterana.

Ključne reči: Thymus, esencijalna ulja, p-Cymene, gama-Terpinen, Thymol, Carvacrol, GC/FID. Naučni rad

Rad primljen: 06. 10. 2019.

Rad prihvacen: 02. 11. 2019.

Rad je dostupan na sajtu: www.idk.org.rs/casopis

(c) 2020 Authors. Published by Engineering Society for Corrosion. This article is an open access article distributed under the terms and conditions of the Creative Commons Attribution 4.0 International license (https://creativecommons.org/licenses/by/4.0/) 